\title{
Soft Tissue Sarcoma of the Head and Neck pT1 TNM Finding v8
}

National Cancer Institute

\section{Source}

National Cancer Institute. Soft Tissue Sarcoma of the Head and Neck pT1 TNM Finding v8. NCI Thesaurus. Code C136665.

Soft tissue sarcoma of the head and neck with tumor measuring $2 \mathrm{~cm}$ or less in greatest dimension. (from AJCC 8th Ed.) 